\section{Frank Engster}

Excerpt from Chapter One of Frank Engster's Book: Das Geld als Maß, Mittel und Methode Das Rechnen mit der Identität der Zeit (Berlin: Neofelis Verlag UG, 2014) ${ }^{1}$

Bionote: Frank Engster wrote his PhD thesis on the subject of time, money and measure. He is interested in the different (post-)operaist, (post-)structuralist, form-analytic, (queer-)feminist etc. - readings of Marx's critique, especially in money as a technique and its connection with measurement, quantification, time and (natural) science. Some publications are available on academia.edu

Independent Researcher frankengster@googlemail.com

Abstract: The question of the book is how a radical critique of capitalism is possible when critique in the tradition of Kant and Hegel means that the criticized subject itself has to "give" the measure of its critique. The thesis is that, while in Kant this reflexivity is achieved by transcendental subjectivity and reason and in Hegel by self-consciousness, self-relation of the concept and the absolute reason of spirit, in Marx we find a materialist turn.

The turn shows that capitalist society became reflexive by a kind of self-measurement, done by the functions of money, on the one hand, and the valorization of labour power and capital, on the other. Money, by its function as the measure of value and the means of its realization and mediation, measures in the commodities the productive relations of their production, thus determining from the past valorization of labour and capital the magnitudes necessary for their further productive valorization - and hence for a productive use of money itself. That is how, in money's capital

${ }^{1}$ This excerpt from Frank Engster's Book, Das Geld als Maß, Mittel und Methode: Das Rechnen mit der Identität der Zeit, has been entirely translated into English by Isidora Hennig, in conjunction with the author, Frank Engster, who has approved all final edits. All quotations have been directly translated from their original German sources, which are reflected in the citations. form, the measured magnitudes become reflexive, while money itself becomes in its capitalist self-relation the form to measure the same valorization process which by this form becomes possible in the first place.

The aim of the book is to translate this process into an economy of time, showing that money's quantification of social relations is nothing else than this translation itself.

Keywords: labour, value, money, capital, critique, Marx, political economy

\section{Marx's Critique of Political Economy (CoPE) as a Socialization of the Mediation of Object and Subject}

The thesis of this book - that Marx's critique of political economy (CoPE) must reconstruct in the criticized society the conditions of the critique itself - this thesis can be specified: The critique establishes its own conditions in view of the systematic-logical development of the capitalist mode of production and its economic categories. Just where, exactly, does this sought out place of critique reside in this development?

If in Marx's categorical development in CoPE, individual categories of political economy share an inner necessity and show an interdependence, then the inner necessity and interdependence must reside in mediation. The individual categories, just like the economy as a whole, must share one and the same mediation, the mediation must be the identical, and thus, the place of critique must reveal itself in the reflection of this societal mediation. The critique of society would thus mean to literally think it from its mediation.

\subsection{The Question of Mediation of Subjectivity and Objectivity}

If the mediation of society is the object of social critique and if the mediation is developed analogously to the concepts of critique from Hegel and Kant then the mediation thus appears to affect nothing less than the constitution of concreteness (German: Gegenständlichkeit). Concreteness means that there is no specific object for the subject and also no objectivity par excellence, instead it means the 
opening of both objectivity and subjectivity. Thus, it is about their division and concreteness as such. The critique appears to have to aim, in its essence, between objectivity and subjectivity, towards a negative, but for objectivity and subjectivity, insofar as constitutive of and productive of being; both must be thought of from the same mediation. Simply summarized, it is about that mediation put in the middle point between objectivity and subjectivity, which in modern philosophy already stands at the middle point and had experienced Kant's and Hegel's systematic development.

But it also seems to be about - and this is Marx' materialist turn and intervention into philosophy - the translation and transference of this mediation into a societal and specific capitalistic mediation and its understanding as an economy. This economy, no different than Kant and Hegel's concept of mediation, must be constitutive of the relation between the social/societal objectivity and the social/ societal subjectivity. This means that the economic mediation must constitute not only that societal/social objectivity which becomes the object for a subject, but also must define the categories and concepts of thought and actions according to this subjectivity as well. In short, subjectivity must be obtained through the same mediation, so that the subject, too, becomes an object in the economy. Therefore, it makes no sense to want to ground subjectivity in an anterior fashion or independently from the economy thus defined.

And at first glance it indeed seems as if Marx's CoPE has socialized through the categories of political economy a mediation that in German Idealism was conceptualized as a mediation by notion and mind and developed as reason (Kant) and Spirit (Hegel). Marx says in a very famous expression that the social being determines consciousness, and if, furthermore, the social being is to be determined as an economic being, than the economic being on the side of social objectivity must also produce a corresponding consciousness and thought-forms on the side of subjectivity. And indeed Marx shows, especially when it comes to value and its appearance by the realization in the sphere of circulation, briefly on the "surface" (Marx) of society, that the objectively-valid determinations of economy correspond to the necessities of thought, and that this relation of correspondence between the economic being and the (everyday) consciousness can be rediscovered in both the philosophical self-un- derstanding and in the political and legal constitution of civil society. At first glance, it appears as though Marx has grounded a mediation which in Kant was grasped as a rational synthesis, and in Hegel as a labour of the concepts in the reproduction of society and developed in materialist terms.

But at second glance, the socialization brings with it a significant turn. Marx goes beyond the mere socialization of the rational, or rather spiritual-conceptual mediation, since he accounts for a societal/social mediation which is withdrawn from the individual realization, as well as from the society as a whole, and remains unavailable. The withdrawal corresponds to the blindness and primordialism of the social mediation, and it is precisely this deprivation and primordialism that produces in the consciousness not only necessary, but also false ideas, but, in fact, these false ideas nevertheless enter into the economy directly and are a part of its functioning.

Thus, by Marx, two contradictory demands have been given to critique; to a critique that must unify the contradiction in a unity of social and epistemological critique. On the one hand, it must be shown that the social being determines the consciousness, on the other hand, this consciousness is as necessary as it is wrongly determined and nevertheless part of social being. Should both of the demands be fulfilled, then the mediation between objectivity and subjectivity cannot merge with its equivalence, as it is, after all, the case in Kant's and Hegel's conception. Marx, therefore, does not show in Capital that objectivity corresponds to itself in subjectivity, nor does he show why objectivity necessarily comes to consciousness falsely and therefore does not correspond to itself in subjectivity. He takes a step back and first shows something else, namely why objectivity corresponds to itself. The social mediation must first of all, so to speak, create an objectivity in which the society blindly and unconsciously becomes an object to itself, and also objectively corresponds to itself. Marx determines consciousness from this objectivity, from this unconscious but objective self-mediation of the society: it is what he names the "social being" or the "pure social relation." However this unconscious self-mediation might be present in the thoughts and actions of the subjects, and however its conscious thereby corresponds or does not correspond to the objectivity of society: the relation is first of all objective insofar as for 
the subjectivity a self-relation literally is given, namely through the mediation of the economy with itself.

In order for the critique to catch up with its own conditions through the criticized capitalistic society, it seems as though this self-mediation must be developed first. In its self-mediation, social objectivity constitutes itself, to which, in turn, the subjectivity must correspond - but not without an inversion and not without a socially necessary and false consciousness. Radical critique seems to have to situate its own justification in this relation between the social objectivity and subjectivity, quite so, as if the critique could justify itself by depicting the self-mediation through which, on the one hand, the economy produces objectivity and, on the other, a subjectivity that corresponds to the objectivity and yet misunderstands it, and must misunderstand it.

\subsection{The Social Mediation by Labour and Value}

There is the assumption that Marx succeeded this critique from the standpoint of labour. Followers and critics of Marx alike have held the opinion that Marx had justified the mediation and reproduction of society through labour; a labour which is, according to classical Marxism, the metabolism with nature, the eternal necessity for man and society, the inner belt of the socialization and the common (red) threads of history. Labour should be the social essence which produces the same social/societal objectivity through which the subjects are (re)given the social determination and productive power of their own labour and of, more generally, social praxis.

Classical Marxism also held the opinion that, from the same standpoint of labour, Marx was also able to determine the inner division and the contradictoriness of capitalist society and to demonstrate in them the driving force and the motor of (historical) development. In the divisions and contradictions, in particular in the class division through the private ownership of the means of production, through the exploitation as well as the unplanned and anarchic application of labour, shall the reason finally be found as to why objectivity and subjectivity cannot - yet - correspond to each other, as the relation between the social objectivity produced and mediated by labour, on the one hand, and the subject of labour and its consciousness, on the other, is a relation of class antagonism and foreign expropriation and domination, determination and exploitation.

This critique of capitalism, which became simplified as traditional Marxism, has also resulted in a "traditional" idea of communism, and this idea of communism, too, arose from the critique of the capitalist mediation of subjectivity and objectivity. What does this idea look like? It was the high aspiration of traditional Marxism to compete with the legacy of German idealism and its conception of subject-object, which was finally developed by Hegel as an "absolute idea," and to socialize the mediation of subject and object through labour. "Socializing" means that, on one hand, traditional Marxism sought to lead the idealistic determination of the (absolute) idea back to the essence of social mediation, namely to labour and its class, and, on the other hand, the absolute idea was to be revolutionized by this socialization and thus take on a communist determination. But what does this socialization mean in regards to idea, and even the idea of the absolute idea or the idea of the absolute?

What philosophy understands by the term idea, but also how it is understood in traditional everyday use, is that consciousness makes itself an image or a presentation. In German Idealism, under the title "idea," the mediation of subject and object would be thematised. The question of the mediation of subject and object was the question of its identification, and this identification, according to German Idealism, is done by mind and reason; with Hegel, the idea was developed even, as already said, to the "absolute" idea, done by a supra-individual "Spirit" and the "logic of the concept", and the individual subject has to be understood form this overarching supra-individuality. However, in what way the grounding of the identification of objectivity and subjectivity in German Idealism and its absolutisation with Hegel was conceptualized is not decisive here. What is decisive is only that the identification has been made by mind and reason, for here, traditional Marxism claimed, alongside Marx, a critique of idealism and even a revolutionization of philosophy as philosophy, an overcoming of philosophy by its practical realization. The Marx-oriented critique of capitalism aimed to show that the identification between subject and object cannot be merely intellectual-conceptual, nor purely spiritual-ideal; rather, the identification must also be carried out practically and be sen- 
sual-active. Furthermore, to identify and comprehend objectivity through consciousness, this objectivity must firstly be produced and appropriated in this practical way. The objectivity must consequently be understood from its practical social and historical becoming and changeability, or rather, objectivity always already exists in this becoming. In any case, the identification between subject and object cannot be made by a labour understood in the purely conceptual-spiritual sense. It cannot be the Hegelian concept of labour that is ultimately attributed to a conceptual reason, to an overreaching (world)-Spirit, or, even, to a higher divinely-creative being, and which would therefore ultimately have to remain purely negative and unavailable. The work of identification is rather - or firstly, before even the conceptual work of consciousness - the specific social practice and the productive power of a particular class, the working class.

If, therefore, the (materialistic) "socialization" of the philosophical concept of idea means to relate the identification of (social) objectivity and subjectivity to labour, and if this identification is practically done by the subject of labour, the working class, then in this socialization of the idea so too is the idea of communism already created. More precisely, in the socialization of the idea, both a critique of capitalism and its revolutionization are created, as the traditional critique of capitalism goes, simply said, that the working class must realize the power of identification of subjectivity and objectivity, by becoming aware of the overarching social determination, purpose and productive power of its own labour and praxis.

However, this determination and productive power of labour in capitalism cannot come directly to consciousness and be practically applied. On the contrary, the working class must at the same time recognize the heteronomy and foreign domination, which lie in the capitalist privatization and implementation, foreign domination and exploitation of labour, its means and their products. The working class, therefore, should first anticipate the identification of the object and subject in an ideal way, like becoming aware of the idea of communism, so that precisely because of this anticipation the need of a revolution becomes aware to actualize in communism the identification then in practice.
It is pointless to argue that such ideas can be attributed to Marx. It is more important that not only have such ideas been cleared up in the meantime, but that Marx had already cleared them up himself. However, this was largely overlooked in the course of the renunciation of traditional Marxism and its concept of labour. For, even if today a radical social critique from the standpoint of labour seems to be outdated, and even if an extensive critique and adoption of such a critique has taken place, it has nevertheless remained largely unnoticed that Marx, in the Critique of Political Economy, does not give a positive determination of labour in the conventional (social-) scientific sense. The determination of labour is done, in contrast, alone, through specific distinctions, and these distinctions don't lead to a (social-) scientific or a merely formal-analytical determination of labour, but rather to its critique. They lead to a critique that does not amount to an empathic liberation of labour, instead, Marx simply shows that, in capitalism, through specific capitalistic distinctions, so too the specific capitalistic determination of labour is made. Even less, Marx does not show that labour, through its social determination and its productive power, produces society and its determination. Rather, he shows quite the opposite, how labour itself is produced and determined. He processes the way in which the capitalist relation of production brings labour into being, sets it into productive power and increases its power. According to Marx, it goes with the fact that labour itself must be produced together with its productive force and its overarching social purpose, and for this, the critical distinctions in the concept of labour are essential.

The most important and thoroughgoing distinction that Marx makes is the distinction between concrete and abstract labour, followed by that between labour and labour power and between living and dead labour, or labour and capital, and necessary and surplus labour time. All of these distinctions ultimately serve to distinguish between the material labour and (re)production process of society and a process of valorization of purely quantitative values, in order to develop and justify, through mediation, the necessity of their correspondence and speculative identity (and to show how this speculative identity becomes real by money is the task of my book). Accordingly, Marx founds with this distinctions in "labour" the category of social mediation par excellence, but only insofar as he founds the afore- 
mentioned distinctions in the concept of labour, those distinctions through which capitalism is mediated and the productive force of labour and its social determination becomes real only via the correspondence between the material (re-)production of society, on the one hand, and the valorization of purely quantitative values, on the other. Moreover, the distinctions are accompanied by such a radical break with everything, what labor may have been before its capitalistic determination (if the general term "labour" can be applied to such non-capitalist societies at all), that the capitalist concept of labour is decisive even for the determination of its 'prehistory'. Marx himself established this in the famous chapter The Method of Political Economy in A Contribution to the Critique of the Political Economy, initially on money:

[...] This very simple category, then, makes a historic appearance in its full intensity only in the most developed conditions of society.

[At the end, he says the same about labour]:

Labour seems a quite simple category. The conception of labour in this general form - as labour as such — is also immeasurably old. Nevertheless, when it is economically conceived in this simplicity, "labour" is as modern a category as are the relations which create this simple abstraction. [...] The simplest abstraction, then, which modern economics places at the head of its discussions, and which expresses an immeasurably ancient relation valid in all forms of society, nevertheless achieves practical truth as an abstraction only as a category of the most modern society ${ }^{2}$

According to this, it is only in capitalism that labour has become such an abstract-general, universal and objective quality that it contradicts its own social and historical origins and gains a timeless, ahistorical validity and necessity. Only under capitalism can it seem as if society has always been mediated and determined by labour as such. But how can labour be specifically capitalist and at the same time be timeless and trans-historically necessary?

${ }^{2}$ Karl Marx, Einleitung zur Kritik der Politischen Ökonomie. In: MEW [MEW= Marx-Engels-Werke] (Berlin, DDR: Dietz 1953 ff: 615-642), 634-635
Marx takes up this paradox in Capital, primarily through the aforementioned distinctions in the concept of labour. The most important distinction comes right at the beginning, namely the distinction between concrete and abstract labour. Only with this distinction does Marx hit the specifically capitalist and yet timeless-universal quality: In capitalist society, abstract labour is distinguished from concrete labour, whereby abstract labour is labour set in value, and as such a quantitative quality, it is brought to a pure, timeless, universal and meta-historical validity. Only capitalist society is based on the valorization of this value, only here the material process of labour and social (re)production is at the same time a valorization of quantitative values.

With the concept of abstract labour, Marx determined the "substance of value," and, at the same time, completely de-substantialized it, because the concrete labour is not set into value as such, even if understood as reduced to the mere expenditure of the brain, muscles, and nerves. On the contrary, for this specific "concrete labour", Marx states that it creates value but has no value at all - only the commodification of labour time does, hence the commodity labour power (and its value is in turn determined by the labour time necessary to reproduce it). With the distinction between labour and labour power, the second, but much less noticed distinction comes into play. It is nevertheless decisive for the determination of abstract labour as a substance of value, because it is not the concrete or living labour that is set into value, but the commodity labour power, and its productive power and its ability to create value, again, does not come through labour in a mental or physical sense, no less than value itself is created by concrete labour. On the contrary, even the productive power and the potentiality of the commodity labour power are determined by Marx in purely social terms: they do not lie in the mental and physical characteristics and abilities of the worker or even the human as such, but result from the relation of commodity labour-power with capital.

Here, in the concept of valorization by this relation, Marx makes the third decisive distinction within the concept of labour, namely the distinction between living and dead labour time. The productive power of valorization ultimately lies, just as the distinction between "dead" and "living labour time" already suggests, in a temporal re- 
lation, namely in the relation which the commodity labour-power, through its labour-time, enters into with its own past, quantitatively accumulated and objectified in capital as dead labour-time, whatever capital's qualitative forms might be. It is this productive power between the labour-time of the commodity labour power with its own past on the side of capital, which, in the results of this relation, the commodities, are realized through money, thus yielding the substance of abstract labour. This relation also sets the relation of "necessary" and "surplus labour time" in power; by this distinction, Marx addresses the exploitation of this surplus labour time as profit, which is, hence, a practical distinction in the sense of a separation and detachment of the exploited labour time from all physical reality.

Here, it does not matter yet in which way the social determination of labour is made by the mentioned distinctions, and how the labour becomes identical in quality; this will be the task of a later section. For the time being, what is of critical importance are only the distinctions as such, because they provide information about the method and the status of Marx's Critique of Political Economy. If the social determination of labour is made by Marx only through critical distinctions, and if it is especially the separation of abstract from concrete labour, which allows labour to become the identical quality of society, then social critique cannot be carried out from the point of view of "the" labour. Labour is thus indeed not the category of social mediation per se, however, a critical presentation of social mediation through all of the distinctions and by the development of abstract labour and the concept of value seems to be the way of critique. Marx expressed himself accordingly in the Grundrisse: "To develop the concept of capital it is necessary to begin not with labour but with value, and, precisely, with exchange value in an already developed movement of circulation." 3 The question of value could thus be the first question for the critical development of capitalist society, and the same in several regards:

- In logical-systematic terms, value seems to be the starting point for the development of the capital form, because it is its abstract and indeterminate determination: value is

${ }^{3}$ Karl Marx, Grundrisse der Kritik der Politischen Ökonomie. In MEW (Berlin, DDR: Dietz 1953: $871-872), 183$. already completely determined precisely by its indeterminacy, which is the first "determination." On the other hand, value is the result of the capitalist mode of production, which is yet to be developed. Value is, according to Marx, "a purely social relation," into which "not an atom of matter enters," while Marx wants to justify the valorization of valve by which value emerges in the first place. The status of value as beginning and result is thus analogous to the "pure being" (and "nothing" in their "becoming") with which Hegel starts his Science of Logic, but value is a pure social being (and nothing in becoming). In addition, due to valorization, value is quantitatively determined, it is always the exchange value of a particular commodity. According to this, value is both an indeterminate social relation and the result of its own valorization by which it is always already quantitatively determined as the value of a determined being, a commodity. It thus seems that value is both an indeterminate being and always a quantitatively determined being as it is to be developed as the determination itself (just like Hegel develops being, nothing and becoming to the form of determination itself, or rather, he develops it as the form of being's self-determination).

- Furthermore, the question of value seems to be the first question for social critique, because value is the social quality par excellence (again, just like Hegel develops in the Science of Logic the pure being and its negativity as the quality as such). If value, according to Marx, is the "purely social relation" in which "not an atom of matter enters," it must be a purely and ideal quality; that quality which is without any quality and hence negative; the quality of a purely ideal identity or even of identity as such. Value is then also by no means to be equated with exchange value, which is always already a quantitatively determined value of an individual commodity - and not the social relation purely as such (like Hegel distinguishes the pure being from the "determined being," which comes by the relation of "something and another"; this relation is what is at stake in Marx' famous "valve form analysis"). 
- A fortiori, a distinction must be made between value and price. In the price, value has its determination and appears on the surface of society as the property of a determined being, and this status of the society "before" its appearance, and the negative essence which is brought to appear as price, is developed by Marx in the first place. The price is not included in this development until after the development of value and its valorization, and so far, price is the real and true object of critique, although it appears only in the third volume of Capital. Unlike the bourgeois economic theory, which does not clearly distinguish between value and price, Marx aims to show that, in the appearance of prices, precisely that social transformation has disappeared, which should be the true object of economic science and is to be justified and criticized through the development of value. For the critique of the appearance of society, the distinction between value and price is therefore essential, indeed, the distinction falls into the essence of society itself.

- If the question of value aims at that negative essence which in the price appears, as well as disappears, it is already a critique as a question, namely a critique of that very bourgeois science, which did not even ask the question of value in a radical sense and may not have been able to do so because of its methodological self-conception: "It is hardly surprising that the economists, quite under the influence of material interests, have overlooked the formal content of the relative expression of value, because before Hegel the logicians by nature even overlooked the formal content of the paradigms of judgment and inference." 4 In any case, Marx states that political economy "has never once asked the question why labour is represented by the value of its product and labour-time by the magnitude of that value." 5 This applies all the more to the "vulgar economy," which Marx distinguishes from classical economics. While Marx critically appraised the fact that in classical economics value was still linked with either labour (Smith, Ricardo) or with

${ }_{4}$ Karl Marx: Das Kapital: Kritik der politischen Ökonomie, Bd. 1. In MEGA [MEGA=Marx-Engels-Gesamtausgabe] II/5 (Hamburg, 1867), 32 subjective use (Bailey), the vulgar economy, despised by Marx, and today's macroeconomics have gone over to prices alone, and do not distinguish between value and price, and certainly not in a critical sense.

- Therefore the question of value could be the primary, "first question," for social critique. Marx himself seems to suggest this, for he begins Capital with an implicit critique of the ways in which value was represented in the political economic theory of his time. This implicit critique is made explicit by the exposition of value itself: Marx explicates the critique of value by determining its substance and its form (these are labour and commodity) as well as through the famous analysis of the value form of the commodity (reconstructing the necessity of a unity of money and value). But before an answer is given as to whether a critique of society can be carried out from the standpoint of labour, through the development of the concept of value and through the constitution of social/societal objectivity, the history of its reception should have its say first, last but not least, since value has become the (secret) center of the discussion on Marx since the 6os and 70s, at least in the German-speaking countries.

\subsection{Critique of Political Economy through the Development of the Concept of Value. The Outcome of the New Marx-Reading}

In the first decades, indeed in the whole first century after the publication of Capital, value was, almost without exception, not accorded primary importance, neither for capitalist society nor for its critique. The socialist movement and the socialist states mostly saw value as a mere economic quantity; consequently, they did not see in Marx's development of value an epistemological or philosophical challenge, yet they did not even see value as specifically capitalist. The few discussions of economic theory that were interested in Marx's concept of value were developed immediately after the publication of Capital, and, ironically, took place within inner academic circles and the environment of bourgeois theorizing - so at quite a distance from the labour movement.

The situation did not change, fundamentally, until 100 years after 
the publication of Capital with the so-called New Social Movements and the New Left. They emerged in the Western industrialized nations in the 1960 s (and in some niches in Eastern socialist countries) and were an expression of the need for the renewal of radical critique in general, and, more specifically, of the consolidating postwar society; they were also already a reaction to the crisis of legitimacy of traditional Marxism and real socialism and thus an expression of the disintegration of the traditional socialist movement and its mode of critique. Thus, this is how it came to be that around the mid-196os a new - operaist, structuralist, feminist - reading of Marx began to revolve around the central categories of Capital, and, also, especially the form-analytic reading of, in the meanwhile, the so called German "New Marx-Reading," around the concept of value. On the one hand, these new readings allowed for a distance from the orthodox Marxism of the "Eastern Block," and the communist parties of the West, and, on the other hand, it worked to connect more directly to Marx's critique and to do justice to it in a proper orthodox sense. The new readings of Marx are not at least "new" in their insights that the clarification of the method of critique and the mode of presentation of Capital, as well as the clarification of the relation to Hegel's dialectics cannot succeed without a reconstruction of the central economic categories, and that these categories, in turn, depend on the development of the concept of value.

However, the various new readings of Marx, in an attempt to define Marx's concept of value, have produced problems rather than solutions. Better said, they have brought about an appropriate awareness of the problems that existed in the first place. This already begins with the fact that a problem was seen in the determination of value at all, as the socialist and worker's movement and the social democracy of the first hour, and then the states of real socialism, had seen in Marx's determination of value, above all, a solution, namely, the justification of value by human labour. Moreover, they have consistently referred to this work affirmatively and, with Marx, have presented not so much a critique of labour as a critique in the name of labour. Here, Marx's concept of value has been consistently positivistically reduced to a left-Ricardian, objective labour theory of value; the same, however, applies to the Marx-critics in bourgeois economics.
Although the new readings of Marx have largely overcome the "labour theory of value," which supporters as well as critics imputed to Marx and had found an implicit agreement about, the attempt to determine value has yielded quite different and even contradictory interpretations. The concepts of value become even broader if one considers the discussion of Marx as a whole - then the determinations of value vary from the aforementioned left-wing Ricardian, substantialist interpretation in the sense of an objective labour value, to the attempt to derive value as a product from the form of commodity exchange and the abstraction made in exchange, up to views which regard value as something subjective, existing in thought only, or, like Cornelius Castoriadis stated, as purely imaginary (whereby the imaginary is again "more real than all reality"). It would seem then, as though all possibilities of determining value have been used. There have even been repeated talks of an end of value and the law of value, most prominently by Antonio Negri and Michael Hardt who call for a bio-political replacement.

If one tries to assign certain directions of social critique to the various concepts of value, then social democrats and the workers' movement of the first hour, as well as Marxism-Leninism advocated the above-mentioned left-Ricardian and substantialist view, according to which value is ultimately formed by the labour spent for the production of commodities. Critical Theory and its environment revolve around an ideologically and epistemologically oriented definition of exchange value as a necessarily false appearance that mediates between objectivity and subjectivity. Structuralism and post-structuralism, as well as operaism and post-operaism, have also made a departure from the positivism and substantivism of the objective labour theory of value, but in a different way than Critical Theory. Operaism and in particular post-operaism have (bio-)politicized and even emphatically subjectivized the concept of value. Here, the ideas of an end of value are also found: Post-Operaism, following Foucault, wants to replace the classical labour theory of value with a bio-political concept, circling around concepts of post-fordist production, immaterial labour, general intellect and multitude. In structuralism and post-structuralism, value has also been subjectivized and politicized, here, however, the focus is rather on the economy of desire, the machinic of wishes, and the production of meaning, in recourse to linguistics and to Sigmund Freud and Jacques Lacan's 
reading of Freud. Value was transferred into the field of the imaginary and symbolic and interpreted in terms of a sign - and circulation-theory of value, referring especially to the logic of signification - but mostly without close reference to Marx' analysis of the valve-form (this close reference, however, is mostly missing in operaism and post-operaism and in the first generation of Critical Theory as well). Currently, both strands converge in a critique of domination and power, post-operaism coming from a bio-political valorization of living labour, but also of life as such, and post-structuralism from techniques of signification and governance, population policy, and financial and digital regulation and control.

Derrida's deconstruction can be read as a representation of the problem of the determination of value, and hence of representation as such. Derrida refers explicitly to Marx only in a few places, nevertheless, his deconstruction, in its own way, also pursues a critique of the economy, especially where it involves the production of meaning through scripture and images, signs and language, and where he traces the productive effects of difference in the circulation and postponement of meaning. In doing so, Derrida pursues the necessity that meaning is not given, received, and maintained without temporalization. This temporalization, in turn, must be reflected and founded in the independence of - in a broad sense signs and texts. His claims in this critique, although conceptualized as a deconstruction of the "metaphysics of presence," has more in common with Marx's economic concept of materialism than many materialisms which have explicitly referred to Marx. However, the procedure of deconstruction resolves the question of value in the direction of a circulation theory and subjective theory of value (although subjective in a completely different way than in mainstream economics). In general, the procedure of deconstruction is at odds with all of the aforementioned directions, because Derrida was one of the few interested in an economy of time, even if he did not, like Marx, look for this economy in the valorization of value by labour power and capital, but, above all, in the relation between language and scripture, in order to trace in the temporalization of meaning a materialism of scripture, writing and their marking of a "difference."

In the FRG, where the current so-called New Marx-Reading had begun around 1965, the discussion of Marx was towards Hegel and
Critical Theory. In a so-called phase of reconstruction of the Critique of Political Economy, the definition of Marx's concept of value was mostly based on Hegel's dialectics, above all, to his Science of Logic (and here to the Logic of Being and the Logic of Essence). With authors more close to Critical Theory, where the reconstruction was more strongly oriented towards ideology and epistemology, there are also references to Kant. Although the beginning of the new discussion of Marx was an almost worldwide phenomenon, the discussion in German-speaking countries has been characterized to this day by a particular concentration on the beginning of Marx's Capital, the value-form analysis and the concept of value; it also incorporated insights to a greater extent than elsewhere, obtained from the second MEGA-edition on Marx's elaboration of CoPE.

If, despite the diversity of all of the contributions, one looks for a common simplified result, one will find that instead of a kind of a coherent theory of value, two poles have emerged. The one pole defines value as a social relation formed by labour and production, and the other pole is the development of value as a social relation formed by the exchange of commodities and the abstraction made in exchange. This indecision within the interpretation of Marx's concept of value, however, points to the undecidable status of its determination itself. The determination of value must seem to have an undecided status, because it can neither be clearly defined through a critique of bourgeois economic theory, nor by an independent (even "Marxist") theory, at least not through a theory in the sense of a conventional (individual) science. If the interpretations of Marx's concept of value turn out to be so different, and if, in addition, they divide into two poles and have an undecided status between critique and theory, this suggests the conclusion that, already, Marx himself had to deal with such a quandary in determining value. And it suggests that both the indecision in Marx's representation of value - especially the dichotomy between substance and form - as well as the indecision in the status of its representation - in between critique and theory - are not a lack of unambiguity, but, conversely, are necessary for a coherent representation of value. If Marx's development of value is deliberately contradictory, and if no closed, contradiction-free theory has been able to take its place so far, then a certain undecidabilities and ambivalences seem to belong to it, if not to value itself, then at least to the ideas it evokes, even, and es- 
pecially, when value is to be brought to a stringent critical or scientific representation. Accordingly, a development of value must also address the need that value: the purely social relation, brings forth such different ideas about itself. As one-sided and even inadequate these perceptions and conceptions of value may be, they nevertheless enter bourgeois-capitalist society, and they not only enter into everyday consciousness and its general dealings with the economy, they are also found in the science of economics and in its attempts at a theory of value. To be aware of this ambiguity perhaps distinguishes the new discussion on Marx, since it was the task, par excellence, in the 196os to deal with this dilemma and thus to confront itself with the precarious status of a radical social critique that can neither release itself into a positive, scientific theory of society, nor hold itself as pure negatively or agnostic.

But back to the question of whether capitalist society can be subjected to a critique through the development of value, rather than from the standpoint of labour, and whether value, and not "the labour," constitutes that objectivity that is given to consciousness and subjectivity to contemplate.

Even before, as it were, all the different concepts of value and their ambivalences, the question arises: why can value, hence our very own social being, become an object of critique at all? Why it can be reflected and presented (critically) at all, especially if it is supposed to be a purely social relation and cannot be experienced empirically? And if value must be dissolved into the mediation between objectivity and subjectivity, and, firstly, into that self-mediation which must be reflected as a self-relation constituting objectivity - how can this self-relation be reflected and determined as the essence of social mediation? How can value be identified as the purely social quality par excellence which stays identical in all mediation when this mediation can be nothing else than a negative being, a mere self-transition of the economic essence by purely quantitative values, by "its" values? Or, thinking from the point of view of the criticized society: how can the economy realize the quality "value" for itself at all, and thereby quantitatively determine itself and establish a self-relation? How can the economy transfer and share "its" quality blindly and primordially, exchange and convert it, let it run in circles, destroy and multiply it - and thereby let value become its identical quality in the first place?

If, in any case, only the value-formed mediation and its constitutive meaning for objectivity and subjectivity, and for the form and substance of society is considered, then exactly the condition of possibility of this consideration gets placed out of sight. It has lost sight of the fact that critique must be about the question as to why the purely social relation as such can become an object, and, furthermore, in double or undecided regards. On the one hand, it is a question of why our social relation, in its mediation, unconsciously can become an object for itself so that the economy can primordial-blindly determine itself through the transfer and valorization of values. On the other hand, it is about how precisely this unconscious self-relation and self-reflection can nevertheless become the object of critique - once again, or in a second, this time conscious reflection, as it were. How can it become the object of critique that, in capitalism, society's own relation is the object of an unconscious self-reflection, self-determination and self-objectification through values? And how can critique share the value-based mediation with the criticized society? Why can critique, when it represents value, literally think from the standpoint of the criticized economy? How does the criticized economy itself give us the possibility of its critique?

(In the following it is shown that critique neither has to occupy the standpoint of labour nor must critique develop the critical distinction in the concept of labour to develop value as the pure social relation: for that development of value, critique has to occupy the standpoint of money. Or rather, critique has to show how money literally stands in for an ideal unit of value by which money occupies a universal and negative, yet inaccessible and even impossible "standpoint": money stands in, like a placeholder, for time. Through money, that time is given which becomes the measure for all the relations, which have been shown for capitalist labour. This is because through money, qualitative material reproduction can be organized by, or as, quantitative magnitudes, and by this speculative identity of the qualitative and the quantitative side of the economy, a whole and true "economy of time" (Marx) emerges - time is the common excluded third of the qualitative and the quantitative side of the economy, their speculative identity as such. Critique, in short, has to determine how money, by quantifying social relations, makes time become real.

However, this "standpoint" of money falls, on the one hand, into its 
main functions, its universal and at once finite-quantitative validity, and in its economic circles, and on the other hand, it falls in the valorization of labour power and capital. To bring this double "fall" of time to the point, critique must reconstruct how money calculates for capitalist society with time. Money calculates by its functions and in the form of its economic circles in a quantitative objective and even mathematically exact and at once speculative, overarching and supra individual way for all the individual subjects, but also for the society as a whole, with the identity of time.)

\section{Translated from the German by Isidora Hennig}

